\title{
FUZZY LOGIC IN PROJECT VALUATION: THE BRAZILIAN ETHANOL CASE
}

\author{
Nathan Peixoto Oliveira \\ Institut d'administration des Entreprises (IAE Bordeaux) - Université de Bordeaux, \\ Avenue Abadie, 35, La Bastide - Bordeaux - AQ, France, 33000 \\ nathanpeixot@yahoo.com.br
}

\begin{abstract}
The future scenario instability has a high degree complexity to the investment decision making, especially in a crisis context where there is less chance for inaccuracies. Therefore, this work has the intention to describe and apply the fuzzy logic in a case study, considering different uncertainties of an ethanol Brazilian investment project, such as: international market competition, inflation tax, supply and demand commodity positioning, cash flow projection and MARR - Minimum Attractive Rate of Return - for the investment. The relevance of the method is based on a more realistic estimation scenario related to projects factors variations. Considering it, the result was a positive Net Present Value and a high percentage of chance of success, stimulating your investment.
\end{abstract}

Keywords: Biofuel; Ethanol; Fuzzy Logic; Net Present Value; Project Valuation.

\section{LÓGICA FUZZY NA AVALIAÇÃO DE PROJETOS: UM ESTUDO DE CASO SOBRE O ETANOL BRASILEIRO}

\section{RESUMO}

A instabilidade do cenário futuro gera um alto grau de complexidade na tomada de decisão de investimento, especialmente em um contexto de crise onde há menos chance para imprecisões. Portanto, este trabalho tem a intenção de descrever e aplicar a lógica fuzzy em um estudo de caso, considerando diferentes incertezas de um projeto brasileiro de investimento em etanol, tais como: concorrência no mercado internacional, imposto inflacionário, oferta e demanda por posicionamento de commodities, projeção de fluxo de caixa e MARR - Taxa Atrativa Mínima de Retorno - para o investimento. A relevância do método baseia-se em um cenário de estimativa mais realista relacionado às variações dos fatores do projeto. Considerando isso, o resultado foi um Valor Presente Líquido positivo e um alto percentual de chance de sucesso, estimulando seu investimento.

Palavras-chave: Biocombustível; Etanol; Lógica Fuzzy; Valor Presente Líquido; Avaliação de Projeto. 


\section{Como Citar:}

OLIVEIRA, Nathan Peixoto. FUZZY LOGIC IN PROJECT VALUATION: THE BRAZILIAN ETHANOL CASE. In: SIMPÓSIO DE PESQUISA OPERACIONAL E LOGÍSTICA DA MARINHA, 19., 2019, Rio de Janeiro, RJ. Anais [...]. Rio de Janeiro: Centro de Análises de Sistemas Navais, 2019.

\section{INTRODUCTION}

\subsection{Theme Presentation}

When it comes to valuate projects, Gomes and Duarte Jr. (1991) say that this is one of the most complex issues, because of the uncertainty present in the environment and the level of dependence between subjects. One factor may interfere with the other and it is complicated to choose what part will be considered and what will not.

In addition, with an unstable future scenario, the difficulty to define the project economic and financial viability as close as possible becomes more complex. And specifically, in the context of the Brazilian economy, with growth near to zero, there will be less chance for inaccuracies.

Especially in the agricultural sector, subject of this dissertation, there is a strong growth on the part of the United States and also, a tread of emerging countries like China and India in the production of biofuels. This ends up hampering the competitive production of ethanol and requiring advanced mathematical models for project valuation.

\subsection{OBJECTIVES}

With observance in the mentioned setbacks, this work has the intention to describe and apply a fuzzy logic method for project valuation considering concomitantly different variables of the micro and macro economy. Such as international market competition, inflation tax, supply and demand positioning of a commodity, the financial information of the enterprise analyzed, its cash flow projection and the minimum attractive rate of return for the investment.

For all the items considered in the valuation model, there will be inserted their uncertainties and as a result, it will be given the closest value for a project investment decision. Also, as a study case, this dissertation aims to solve the specific problem of a Brazilian ethanol plant investment.

\subsection{JUSTIFICATION}

Methods as the NPV - Net Present Value -, discounted payback, internal rate of return and others do not consider the uncertainties of the economic model into a decision. Consequently, the results may not be so verisimilar when applied in a real and complex investment project.

Thus, the dissertation is committed to present a different and simpler method using fuzzy logic, applied to project valuation. Gomes and Duarte Jr. (1991) affirm that one of its advantages is the possibility to use quantitative, but also qualitative data for a decision. In addition of being closest to the reality, what is not found in unilateral methods. Besides that, the method allows the decision maker to use different aspects simultaneously, where many different issues impact on the final result.

The question that one wants to answer is how to evaluate a project with different items present and also with their uncertainties. For that, it is proposed an ethanol Brazilian plant investment case study to best illustrate the application of the model.

At last, this academic production is intended to students and professional of the area, but also those who make the use of it as an increase of learning. Its comprehension permits 
readers to use an accessible method to analyze and select projects with a diverse number of criteria.

\subsection{Methodology}

Based on a case study, the study methodology was organized on a four steps process:

a) Preparation: environment setting, problem definition, work objectives and motivations;

b) Data selection: bibliographic research;

c) Data treatment: use of the case study as a research methodology and

d) Results presentation: work response and conclusions.

\section{FUZZY LOGIC}

\subsection{DEFINITION}

The Fuzzy model has the intention to simulate the uncertainty of the human decision process (Shaw \& Simões, 1999). According to Oliveira Júnior (1999), the most impressive factor is the possibility to measure through mathematical model, qualitative aspects.

Cases as thermal sensibility may vary from individual to individual, such as the sense of hot, neutrality and cold. For that, Fuzzy can take number or even range of values to define each state (Oliveira Júnior, 1999).

The first paper regarding this theme was published by Lotfi Aliasker Zadeh (1965), named as Fuzzy Sets. The professor emeritus of Berkley noticed the computational problem based on Boolean logic. The binary $\{0,1\}$ was incapable to identify ambiguous situations.

Although, for Shaw and Simões (1999) there is a great discrepancy between bivalence and the real world optical. By Zadeh (1965) proposition, it is possible to belong partially to the set $\mathrm{A}$, not being only 0 or 1 , but also values between these two numbers, as in picture 1.

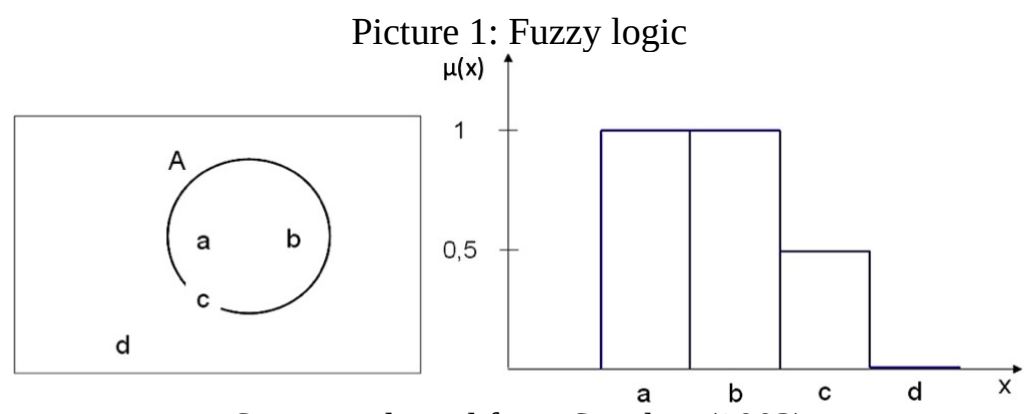

Source: adapted from Sanches (2003)

By picture 1 , it is observed that $\mu A(x)$ will not be anymore the function that defines the inclusion of the element in set $\mathrm{A}$, but the level of membership, measured between 0 and 1 . And despite the confusion of membership being a probability, the author emphasizes that Fuzzy has not statistical characteristics (Zadeh, 1965).

\subsection{FUZZY NUMBERS}

Sanches (2003) says that each Fuzzy number is not an element, but a subset of the real numbers. It means that, what is common to be zero, as an element, for this concept, can be almost zero. According to Shaw and Simões (1999), the Fuzzy logic assume that the level of membership is obtained gradually, not abruptly, based on the concept of uncertainty, as can be seen by the example of the rain possibilities in table 1 .

Table 1: Rain Fuzzy criteria

\begin{tabular}{|c|c|}
\hline Membership Level & Rain Intensity \\
\hline 1.0 & Storm \\
\hline 0.8 & Heavy Rain \\
\hline
\end{tabular}




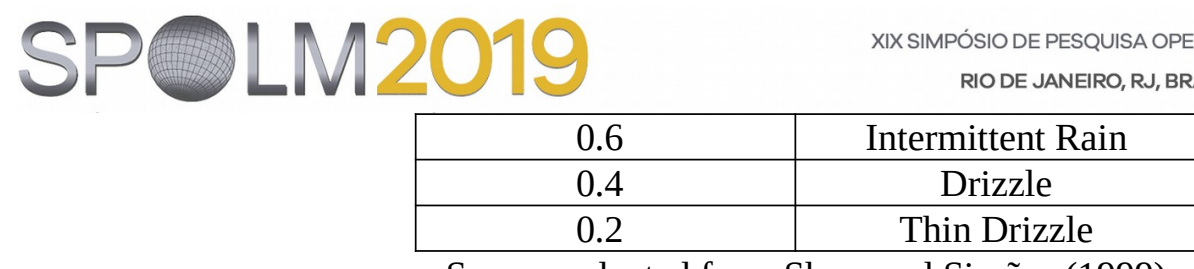

Source: adapted from Shaw and Simões (1999)

The illustration helps to differentiate Fuzzy membership to probability. While in the first 0,8 demonstrates the possibility of heavy rain, in the second, 0,8 is the percentage that expresses the probability of simply rain.

\subsection{FUZZIFICATION AND DEFUZZIFICATION}

The purpose of the fuzzification consists in changing input variables into fuzzy ones. These will be used as the basis of calculation and inference. Then, the results of the fuzzy model will be transformed into real outputs, so they can be easily interpreted (Oliveira, 2008). The symbolization of this model is found next in picture 2:

Picture 2: Fuzzy model

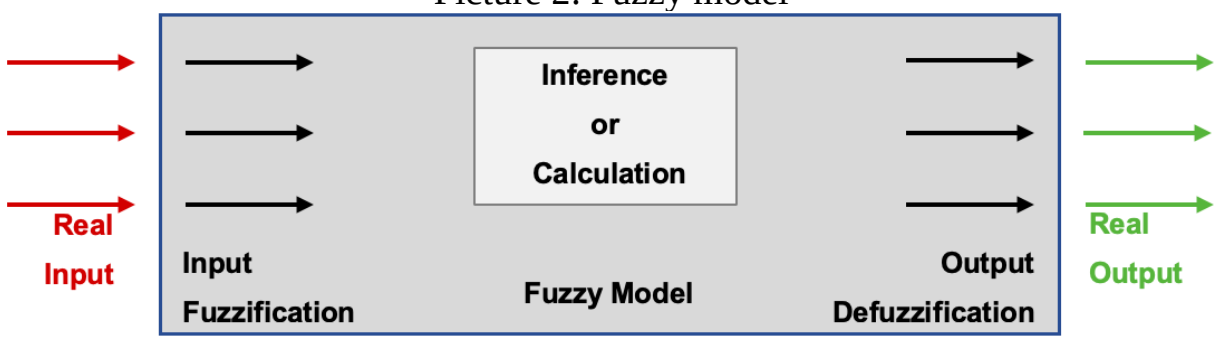

Source: adapted from Oliveira (2008)

Oliveira Júnior et al (2007) say that fuzzification is used to give a better interpretation to the subject analyzed using membership function and linguistic variation. For the process of defuzzification, the objective is to change the fuzzy numbers into a unique discrete number that best represents them (Shaw \& Simões, 1999). Oliveira Júnior (1999) agrees by saying that diffuse numbers are not understood in the real world, then it is important to generate representatives that best summarize the outcomes.

Thereby, there are many different methods to practice the defuzzification, like: by the center of area, by the maximums average and by the distribution of cumulative possibilities. In this work it will be seen and used the first method.

Shaw and Simões (1999) say that this method, also known as gravity center, is calculated through the centroid of area (picture 3). The fuzzy number represents the power of an engine, where a negative value is the possibility to turn in reverse. The results are next:

Picture 3: Defuzzification by the center of area

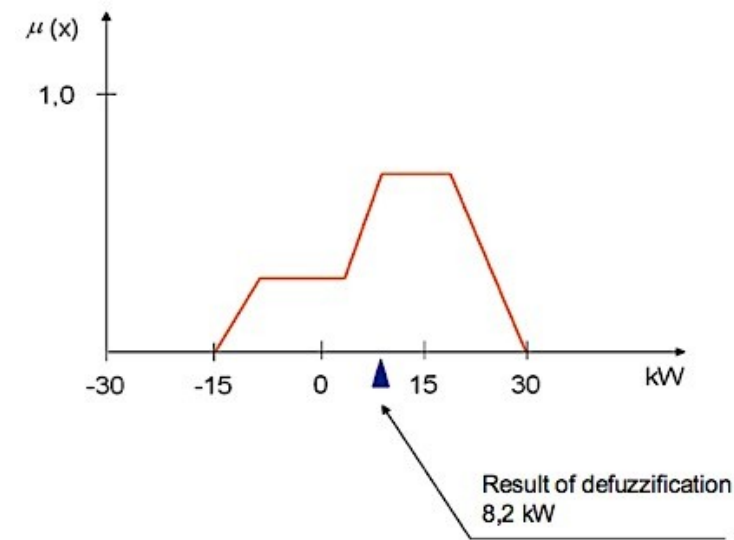

Source: adapted from Shaw and Simões (1999) 
$x=\frac{\sum_{j=1}^{N} x_{j} \times \mu\left(x_{j}\right)}{\sum_{j=1}^{N} \mu\left(x_{j}\right)}$ Eq. (2.1)

$x_{j}$ : is the value of the variable $\mathrm{x}$ of each $\mathrm{j}$ situation;

$\mathrm{N}$ : is the number of iterations used and

$\mu\left(x_{j}\right)$ : is the membership for each $x_{j}$ corresponding value.

\subsection{Fuzzy Logic in Project Valuation}

Oliveira (2008) tells that fuzzy became famous by the capacity to lead with uncertainties and to be applicable to several areas. In the financial area, the method is being used since the profitability analysis of a company, where the balance sheet is the main tool, to even calculate the return of a project, as the example of the internal rate of return (IRR).

Gutiérrez (1989) presents one of the first application of the fuzzy logic to the NPV calculation. In his work, by using the cash flow (CF) and the interest rate (i), the result was a triangular fuzzy number that represents the $\mathrm{NPV}_{\text {Fuzzy }}$. The difficulty resides in the difficulty to interpret fuzzy outputs instead of real numbers. Also, to compare different projects each other, demands mathematical precautions.

Starting from that problem, Chiu and Park (1994) elaborated a defuzzification method for the NPV Fuzzy starting from:

$N P V_{\text {Fuzzy }}=\left[\operatorname{NPV}_{\text {Fuzzy }}{ }^{1(\alpha)}, \mathrm{NPV}_{\text {Fuzzy }}{ }^{\mathrm{r}(\alpha)}\right]$ Eq. $(2.2)$

The objective was to develop both elements of the $\mathrm{NPV}_{\text {Fuzzy }}$ exposed in the formula. Where the left - NPV ${ }_{\text {Fuzzy }}{ }^{l(\alpha)}$ - reproduce the lowest values for the $\mathrm{NPV}_{\text {Fuzzy }}$ and the right $\mathrm{NPV}_{\text {Fuzzy }}{ }^{\mathrm{r}(\alpha)}$-, the highest (Oliveira, 2008).

By $\mathrm{NPV}_{\text {Fuzzy }}{ }^{1(\alpha)}$ and $\mathrm{NPV}_{\text {Fuzzy }}{ }^{\mathrm{r}(\alpha)}$, the $\mathrm{NPV}_{\text {Fuzzy }}$ in the membership between 0 and 1 is:

$N P V_{\text {Fuzzy }}=\left[\sum_{j=0}^{n}\left(\frac{\max \left(C F_{j}^{l(\alpha)}, 0\right)}{\prod_{j=0}^{j}\left(1+i_{j}^{r(\alpha)}\right)}+\frac{\min \left(C F_{j}^{l(\alpha)}, 0\right)}{\prod_{j=0}^{j}\left(1+i_{j}^{l(\alpha)}\right)}\right) ; \sum_{j=0}^{n}\left(\frac{\max \left(C F_{j}^{r(\alpha)}, 0\right)}{\prod_{j=0}^{j}\left(1+i_{j}^{l(\alpha)}\right)}+\frac{\min \left(C F_{j}^{r(\alpha)}, 0\right)}{\prod_{j=0}^{j}\left(1+i_{j}^{r(\alpha)}\right)}\right)\right]$

\section{CASE STUDY}

\subsection{CONTEXTUALIZATION}

Carvalho, Bortolini and Barcellos (2014) say that the increase of pollution and sustainable consciousness, mainly after the Kyoto Protocol signature in 1997 and ratified in 2005, opened space to a new kind of energy. For Greene et al. (2006) the petroleum price was also important and biofuel or agrofuel are of biological origin, which presents a considerable competitive advantage from the sustainable point of view in detriment of fossil ones.

In the middle of XIX century, Brazil became the first country to produce ethanol fuel by its national program developed in 1975, the "Próalcool", right after petroleum big crisis of 1973/1974. The goal was to reduce the dependency of fossil fuels. And it became the world's largest producer, using principally sugarcane as feedstock (PAULILLO et al., 2007).

Kohlepp (2010) affirm that, while the international market competition was rising up, Brazil since 2006, became self-sufficient in oil supply (in 1970, 80\% of the Brazilian oil was imported, representing $47 \%$ of total imported goods).

As in picture 4, national ethanol production had a consistent growth until 2010, 
where were produced 28 billions of liters. And in the year of 2013, the good numbers were linked to the sugarcane low prices on the international market, which were on the lowest level in seven years. Also, because of the existence of mixed mills - capable of producing sugar and ethanol -, redirecting more raw material and reaching 29.4 billions of liters in 2015 (ANP, 2016).

Picture 4: Evolution of sugarcane in Brazil (Ethanol)

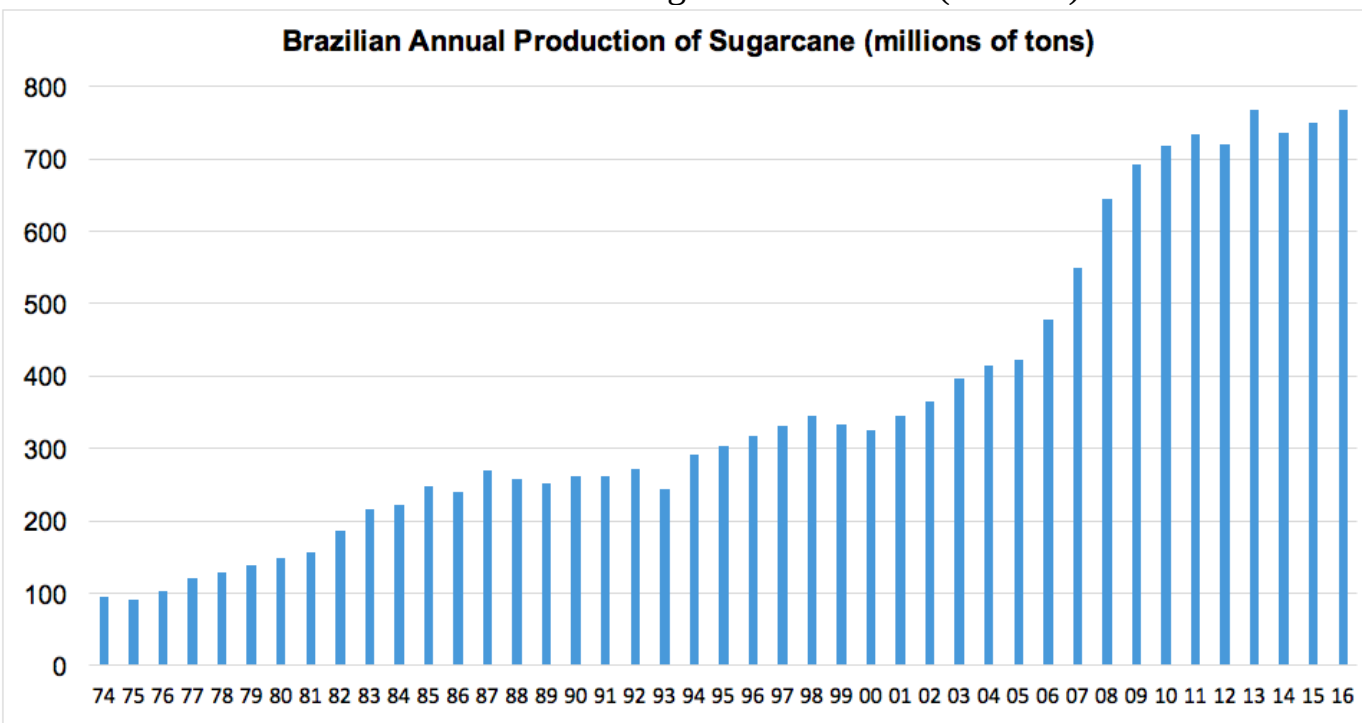

Source: adapted from IBGE (2017)

On the international market, the main ethanol producers are the United States and Brazil, in this order. Other countries do not occupy an expressive position. The evolution of those two countries are quite different in recent years, where the first has its production more than doubled between 2007 and 2011, going from 24.7 to 52.7 billions of liters (ANP, 2016).

The reason for this quick growth is explained by the United States high corn stock and secondly by the low price and high demand of the petroleum, where ethanol represents $10 \%$ of the compound (Parker, 2016). Besides USA and Brazil on the top of the ethanol annual production ranking, there is Europe, followed by China and Canada as in picture 5.

Picture 5: Top 5 ethanol producers

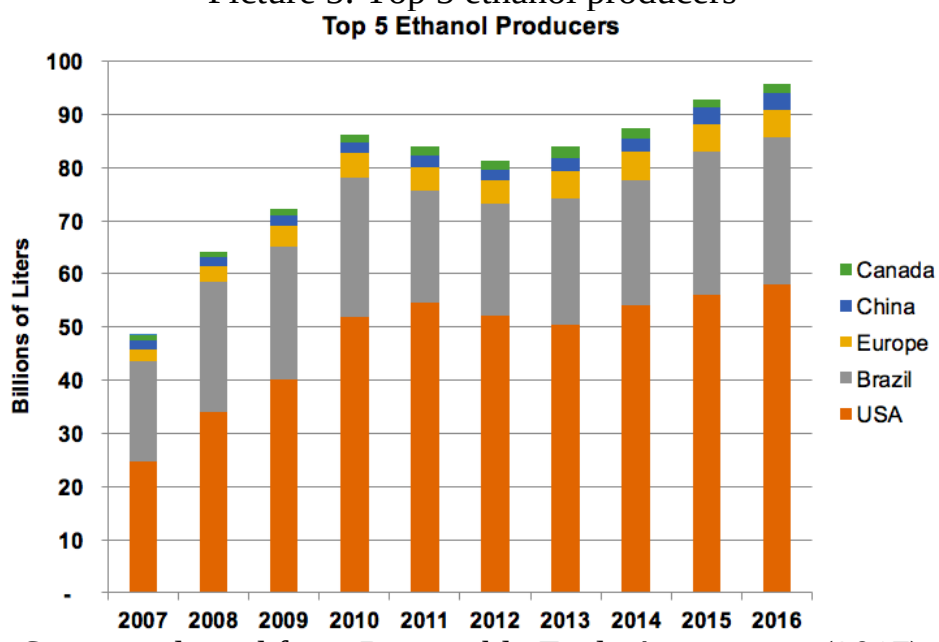

Source: adapted from Renewable Fuels Association (2017)

In this way, can be concluded that Brazil has perfect conditions to produce biofuels as its energy matrix in 2016 was 43.5\% from renewable sources (against 14.2\% of global average), where: $17.5 \%$ are from sugarcane, $12.6 \%$ from hydroelectric, $8 \%$ from wood and charcoal and $5.4 \%$ of others renewables. The fossil fuels participation is decomposed by $36.5 \%$ of oil, $12.3 \%$ of gas, $5.5 \%$ of mineral coal, $1.5 \%$ of uranium and $0.7 \%$ of others not 
renewable (MME, 2017).

\subsection{Project Description}

By the points previously elucidated, the entrepreneur who claimed not to be identified, intended to enlarge his operation in the Brazilian renewable energy sector. He wants to invest in an expansion project placed inside the state of São Paulo, southeast region of the country.

Therefore, the investment comprehends the purchase of a land of 10 million square meters (1,000 hectares or 2.47 acres), a factory for the ethanol production, machines, equipment and office supplies. The 1,000-hectare land is decomposed in an 800-hectare area that can be used for the production of sugarcane, a 100-hectare land reserved for native plantation and the rest of the terrain encompasses the factory, a parking lot, two houses and a land for livestock. The first house will be also used for administrative issues and the second, for the farm caretaker.

According to the IEA - Institute of Agricultural Economics (2017) of São Paulo, for those lands bigger than 242 hectares, with improvements such as properties, are valued in the Brazilian currency at R \$23,395.74 per hectare (or per 2.47 acres). In the land price were already considered the two houses and the livestock animals, but not the factory.

By the production perspective and according to UDOP - Union of Bioenergy Producers (2016), one-hectare plantation produces annually 77 tons of sugarcane and for each ton, 85 liters of ethanol in average is produced. Therefore, considering the total plantation area of 800 hectares, the annual maximum production capacity is 5,236,000 liters of ethanol, with an average demand in the same period around 4,800,000 liters.

Regarding the financial information, the minimum attractive rate or return - MARR - was established as $1.5 \%$ above Selic rate, the basic interest rate in Brazil. According to BACEN (2017), the Brazilian Central Bank, on January $11^{\text {th }}$ of 2017 the rate was found at $12.9 \%$ per year. The economic investment life was defined as 12 years and the residual value at the end of this period corresponds to value of the land, which was not considered as a depreciable value.

\subsection{Project Valuation}

\subsubsection{Case Study Uncertainties}

Each quantitative information has an uncertainty. Thus, for each investment, revenue, cost or expense will have a variation. In the appendix A these items are exposed.

a) Minimum attractive rate of return: as this item is linked to the Selic basic interest rate (1.5\% above), its variation will follow the same trend. Therefore, to obtain the most realistic annual variation for the Selic, the rate was analyzed from 2006 until 2016.

The interest rate was assessed at the beginning and end of each year with its respective variation. The Selic value is calculated as the average daily interest rate, annualized based on 252 business days (BACEN, 2017). With those numbers acquired, the second step was to put the annual variation in ascending order. This will help to obtain the fuzzy membership association and as a consequence, the triangular numbers and the $\alpha$ - cut representation.

The more realistic Selic annual variation is a result of the its defuzzification and the method used was the centroid. The calculation performed and the fuzzy triangular representation are in picture 6 . Thus, $0.8 \%$ is the best choice for Selic annual variation.

Picture 6: Selic annual variation 
b) Residual value and land: it can be noticed that the factory, the machines and equipment and the office supplies are depreciated over time, during ten years. Nevertheless, the land does not reduce the value over time, remaining as a residual value at the end of the project. So, the residual value can be said as equal to the land value.

As already said, the current land value inside the state of São Paulo when it is bigger than 242 hectares with improvements is $\mathrm{R} \$ 23,395.74$ per hectare, or per 2.47 acres (IEA, 2017). And its variation is calculated comparing year by year according to the same source. The result for the best land annual price variation was 10.3\% (picture 7).

Picture 7: Land annual price variation

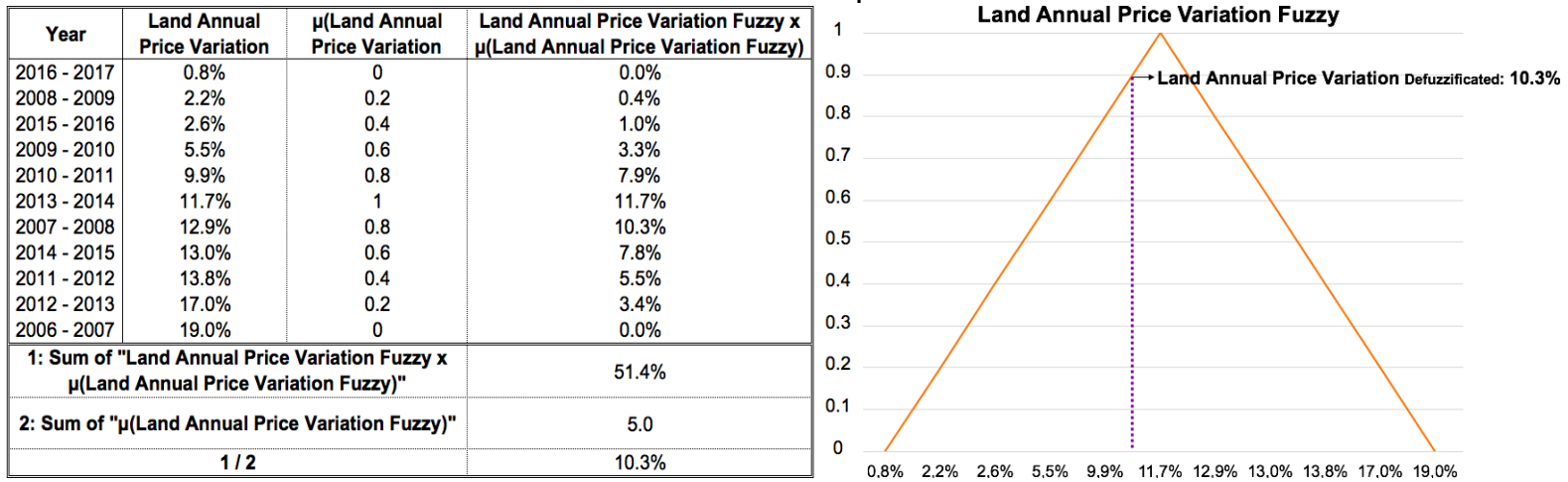

Source: adapted from IEA (2017)

c) Factory, machines, equipment and office supplies: for the investment in this item, was used the analogy estimation technique. It means that, for the same order of magnitude of production, were searched equivalent expenses as paradigm. The variation used was relative to the Selic interest rate as already calculated on item a.

d) Demand: in this step, the inference was the estimation technique used. Thus, during the year of 2016, including its seasonality and excluding outliers, was possible to perceive a variation between $3,696,000$ and $5,904,000$, that represent a variation of $\pm 23.0 \%$ compared to the 4,800,000 average demand of liters of ethanol per year. The demand membership and variation can be seen in picture 8 .

Picture 8: Demand variation 


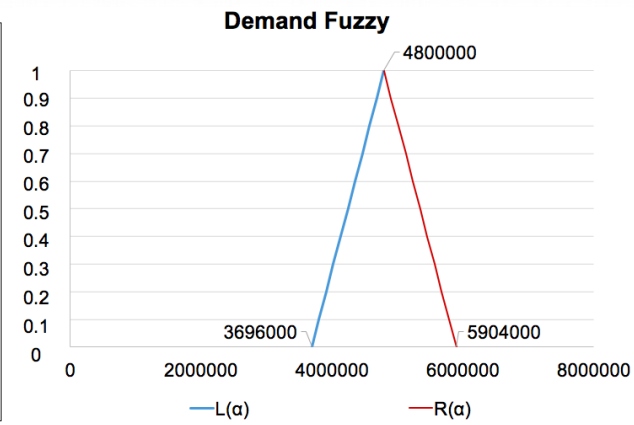

Source: author

e) Selling Price: at the end of 2016, the anhydrous ethanol selling price, by the industry point of view was approximately R 1.87 per liter in the state of São Paulo (University of São Paulo, 2017). It was also studied its annual variation during the period of 2006 and 2016 in the same region and the results are in picture 9. By putting the annual price variation in ascending order and establishing its membership, the next step was to find the defuzzificated value by the center of area method. The math and representation are found next.

Picture 9: Ethanol annual price variation

\begin{tabular}{|c|c|c|c|}
\hline Year & $\begin{array}{c}\text { Ethanol Annual } \\
\text { Price Variation } \\
\text { Fuzzy }\end{array}$ & $\begin{array}{l}\mu(\text { Ethanol Annual } \\
\text { Price Variation } \\
\text { Fuzzy) }\end{array}$ & $\begin{array}{c}\text { Ethanol Annual Price Variation Fuzzy } \\
x \mu(\text { Ethanol Annual Price Variation } \\
\text { Fuzzy) }\end{array}$ \\
\hline 2006 & $-23.6 \%$ & 0 & $0.0 \%$ \\
\hline 2007 & $-11.1 \%$ & 0.2 & $-2.2 \%$ \\
\hline 2010 & $-8.2 \%$ & 0.4 & $-3.3 \%$ \\
\hline 2012 & $-2.3 \%$ & 0.6 & $-1.4 \%$ \\
\hline 2014 & $-1.5 \%$ & 0.8 & $-1.2 \%$ \\
\hline 2016 & $2.4 \%$ & 1 & $2.4 \%$ \\
\hline 2008 & $5.8 \%$ & 0.8 & $4.6 \%$ \\
\hline 2013 & $11.9 \%$ & 0.6 & $7.1 \%$ \\
\hline 2011 & $12.7 \%$ & 0.4 & $5.1 \%$ \\
\hline 2009 & $28.0 \%$ & 0.2 & $5.6 \%$ \\
\hline 2015 & $28.6 \%$ & 0 & $0.0 \%$ \\
\hline \multicolumn{3}{|c|}{$\begin{array}{c}\text { 1: Sum of "Ethanol Annual Price Variation Fuzzy x } \\
\quad \mu(\text { Ethanol Annual Price Variation Fuzzy)" }\end{array}$} & $16.8 \%$ \\
\hline \multicolumn{3}{|c|}{ 2: Sum of " $\mu($ Ethanol Annual Price Variation Fuzzy)" } & 5.0 \\
\hline \multicolumn{3}{|c|}{$1 / 2$} & $3.4 \%$ \\
\hline
\end{tabular}

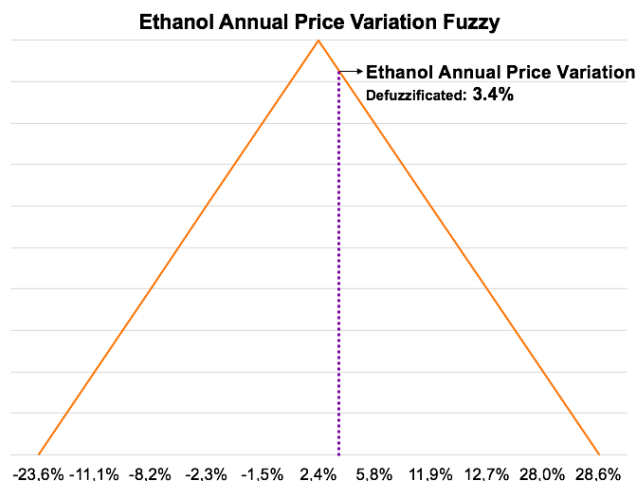

Source: adapted from University of São Paulo (2017)

By the previous picture it is possible to observe a 3.4\% result for the ethanol annual price variation. This defuzzificated value expresses the best value for this item.

f) Remains of raw material: a specialized in biomass digital magazine called Canaonline (2015) published that inside the state of São Paulo (same area as the project is destined), 1 ton of sugarcane produces in average 250 kilograms of bagasse. And according to the production information, a sugarcane ton produces 85 liters of ethanol. Then, 1 ton of bagasse corresponds to 340 liters of ethanol. On the other hand, the average price of 1 ton of bagasse (340 liters of ethanol) is 85 reais (Canaonline, 2016). Then, the remains of raw material revenue would be 0.25 reais per liter of ethanol.

Regarding the uncertainty of this same price, Canaonline (2016) says that, during one year (2015 to 2016) it went from 30 to 150 reais per ton, or by correspondence, 0.09 to 0.44 reais per liter of ethanol. In other words, a variation of $-64.7 \%$ and $76.5 \%$ around the $\mathrm{R} \$ 0.25$ average price per liter of ethanol.

g) Freight: the transportation income is an analogy estimation based on a benchmarking research. So, a healthy value would be $\mathrm{R} \$ 0.53$ per liter of ethanol. Besides that, the uncertainty range is closely linked to the fuel cost variation, since it directly impacts the cost of freight performed by biofuel vehicles. Therefore, it will be a $3.4 \%$ fluctuation, as discovered in item e.

h) Variable costs and expenses: a study ordered by the BNDES - National Bank of Economic 
and Social Development - to the CTBE - National Laboratory of Bioethanol Science and Technology - verified that the current spending to develop the ethanol first generation $(1 \mathrm{G})$ is $\mathrm{R} \$ 1.15$ per liter. While in the future, the second generation $(2 \mathrm{G})$ will be reduced to $\mathrm{R} \$ 0.75$ in average (CTBE, 2015). So, it was considered the present value of $\mathrm{R} \$ 1.15$ per liter of ethanol.

In addition, regarding the uncertainty, specialists considered as $20 \%$ of range. The explanation consists in the fact that the variable costs and expenses discrepancy are directly proportional to the demand variation (23\%). However, with the continuous increase of the second, bills like water, energy and other inputs tend to reduce. The reason is the discounts given to large-scale consumption. Thus, the uncertainty will be slightly lower.

i) Fixed costs and expenses: to define this item, it was chosen the parameterization method. Which is an estimation technique by proportion with similar cases by context and different by order of magnitude. Thus, it was projected an annual amount of $\mathrm{R} \$ 680,000$ and for the uncertainty, as the majority of this value is composed by the payroll, it was indexed to the minimum wage fluctuation.

It was analyzed the interval between 2006 and 2017, that had a $167.7 \%$ of total variation. After that, the next step was to organize the minimum wage annual variation in ascending order and associate with the fuzzy membership. Finally, by defuzzification, it was possible to obtain a $9.1 \%$ as the best range (picture 10), which will be used in the case study.

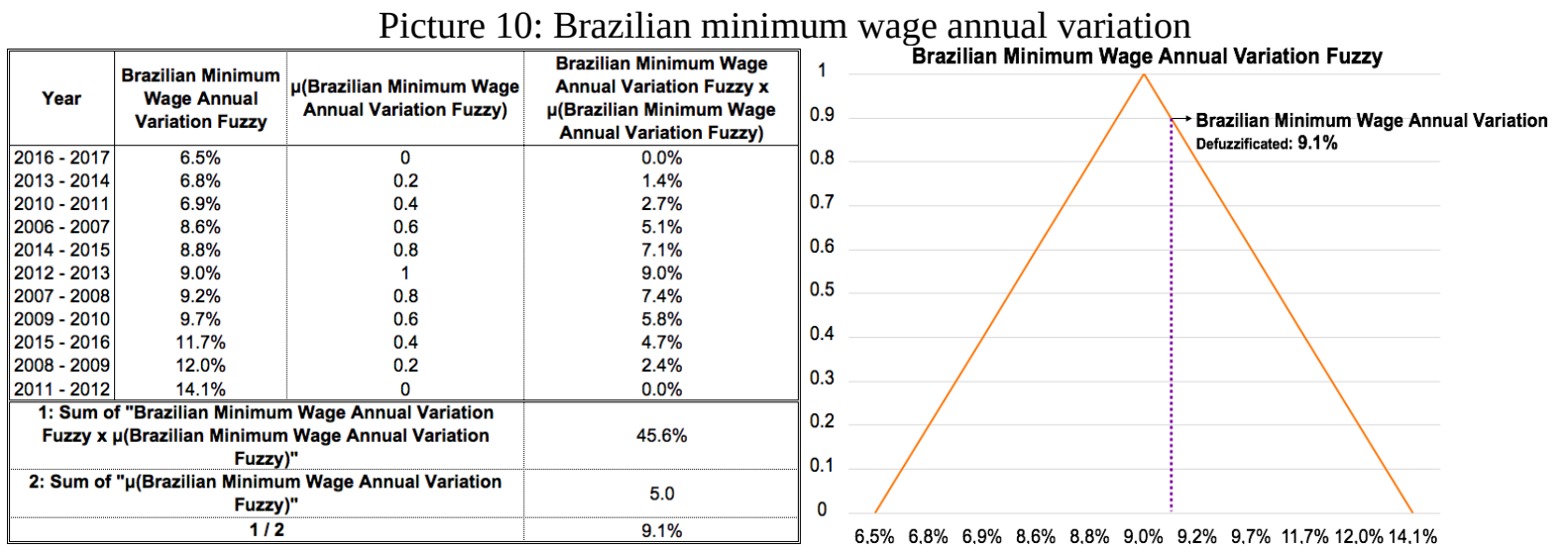

Source: adapted from ADVFN (2017)

Items like remains of raw material, demand and variable costs and expenses in this order, were those with the largest amount of uncertainty by the unpredictability of future scenario. In addition, it is very important to note that, the selling price fluctuation was not expressive. The reason is based on the fact that, while there were years with big increase, also, there were some with emphatic decrease, balancing the average annual variation.

The uncertainty is primordial, because is what fuzzy logic consists of. Different from the conventional way of calculating the NPV, in this method, all the inconstancy is considered relevant and will be part of the study. That explains why the model is so well accepted in changeable scenarios.

\subsubsection{NPV Calculation}

The difference between the Net Present Value and the fuzzy one is the uncertainty present only in the second. And as part of obtaining its number, first the total investment has to be found. Then, the total revenue, costs and expenses, depreciation and residual value so that its value can be achieved.

To obtain the total investment, which is the total amount necessary to operationalize the ethanol generation, the following formula will be used: 
Total investment $=$ Land + Factory + Machines $\wedge$ equipment + Office supplies $=-R \$ 27,454,140.00$ (Eq. 3.1) displayed as:

Subsequently, the total annual revenue obtained from the sugarcane and its bagasse is Total annual revenue $=($ Sugarcane avarege selling price + Remains of raw material average price + Freight a (Eq. 3.2)

The total annual costs and expenses are divided in fixed and variables. The first does not change according to the production volume and the second does. Your calculation does not consider the taxes payed, which will be inserted in the future. The formula is represented as:

Total annual costs $\wedge$ expenses $=$ Variable costs $\wedge$ expenses $\times$ Average demand $+i$ costs $\wedge$ expenses $i-R \$ 6,200,000.00$ (Eq. 3.3)

By the revenue and the costs and expenses, the annual cash flow before taxes will be: Annual cash flow befores taxes $=$ Total annual revenue - Total annual costs $\wedge$ expenses $=R \$ 6,509,920.00$ (Eq. 3.4)

In order to calculate the annual cash flow after taxes, depreciation has to be considered. Some assets will lose value through time and the taxes cannot discount the full value. Therefore:

Total annual depreciation $=($ Factory + Machines $\wedge$ equipment + Office supplies $) / 10=-R \$ 405,840.00$ (Eq. 3.5)

As all the items had the same period of depreciation, which was ten years, in the formula, all of them were divides by ten. So, until the tenth year of the project, the depreciation can be used as a discount when calculating the taxes, after that, the full amount will be taxed.

Desiring to obtain the annual cash flow after taxes, two different calculations must be made: the first, during the years 1 to 10 of the project, where the depreciation can be discounted and the second, from 11 to 12 years where it cannot:

Annual cash flow after taxes (1i10 years $)=$ Annual cash flow before taxes - Tax aliquot $\times($ Annual cash flow $b$ (Eq. 3.6)

When there is no more depreciation from the eleventh year until the end of the project at the twelfth, the formula is:

Annual cash flow after taxes $(11$ i 12 years $)=$ Annual cash flow before taxes - Tax aliquot $\times$ Annual cash flow (Eq. 3.7)

It is important to notice that cash flow during the 1 to 10 years is greater than the 11 to 12 because of the discount on charged taxes, known as depreciation. And finally, with all the previous information it is possible to measure the NPV by:

$N P V=$ Total investment $+\sum_{j=1}^{10}\left(\frac{\text { Annual cash flow after taxes }(1 \dot{1} 10 \text { years })}{(1+M A R R)^{J}}\right)+\sum_{j=11}^{12}\left(\frac{\text { Annual cash flow after taxes }}{(1+M A R R)^{J}}\right.$

By the NPV calculation it is possible to see that, besides the minimum attractive rate of return of $14.4 \%$ per year $-1.5 \%$ above the Selic Brazilian basic interest rate - the project will give a positive return of $\mathrm{R} \$ 3,174,764.07$. However, the environment is full of uncertainty that are not considered in this method, thus, the NPV Fuzzy is used to fill this gap.

\subsubsection{Case Study Fuzzification}

As part of the $\mathrm{NPV}_{\text {Fuzzy }}$ definition, three steps are required to be done: first the fuzzy numbers must be determined, also called as the process of fuzzification, then the calculation is made and finally, the defuzzification, transforming into real world numbers.

The fuzzification is the process to include the uncertainty into the study, so, the land 
example will be used to illustrate the process: with the value of $-\mathrm{R} \$ 23,395,740.00$ and ranging from $\pm 10.3 \%$, the triangular fuzzy numbers are shown next.

Land $_{\text {Fuzzy }}=\left(\right.$ Land $_{1}$, Land $_{2}$, Land $\left._{3}\right)=(-R \$ 25,805,501.22,-R \$ 23,395,740.00,-R \$ 20,985,978.78)$ (Eq. 3.9)

As the land example, the triangular fuzzy numbers and the $\alpha$-cut model were made for each item using only Microsoft Excel ${ }^{\circledR}$, one of the software most widespread in the world, making the study available for a large number of people. The result is in Appendix A.

\subsubsection{NPV Fuzzy Defuzzification}

The process of defuzzification adds verisimilitude to the $\mathrm{NPV}_{\text {Fuzzy }}$. Noting that it ranges from $-\mathrm{R} \$ 13,987,255.54$ to $\mathrm{R} \$ 26,354,962.70$ due to the project components variation, the defuzzificated value will give the best approximation for the real world. The most used method found in the bibliography was the center of area or also named centroid.

Considering $\mathrm{N}$ as 20 iterations, the formula used for the $\mathrm{NPV}_{\text {Fuzzy }}$ defuzzification was:

$N P V_{\text {Defuzzificated }}=\frac{\sum_{j=1}^{N} N P V_{\text {Fuzzy }_{j}} \times \mu\left(N P V_{\text {Fuzzy }_{j}}\right)}{\sum_{j=1}^{N} \mu\left(N P V_{\text {Fuzzy }_{j}}\right)}=R \$ 4,175,286.33$ Eq. (3.10)

As a consequence, the worst and best scenarios for the investment are $-\mathrm{R} \$$ $13,987,255.54$ and $\mathrm{R} \$ 26,354,962.70$ and, by the defuzzification, the greater approximation considering all the uncertainties listed in the study would be $\mathrm{R} \$ 4,175,286.33$. In addition, by the distribution of cumulative possibilities defuzzification is viable to discover the chance of failure or success of the investment. The representation (picture 11) and the formula are next:

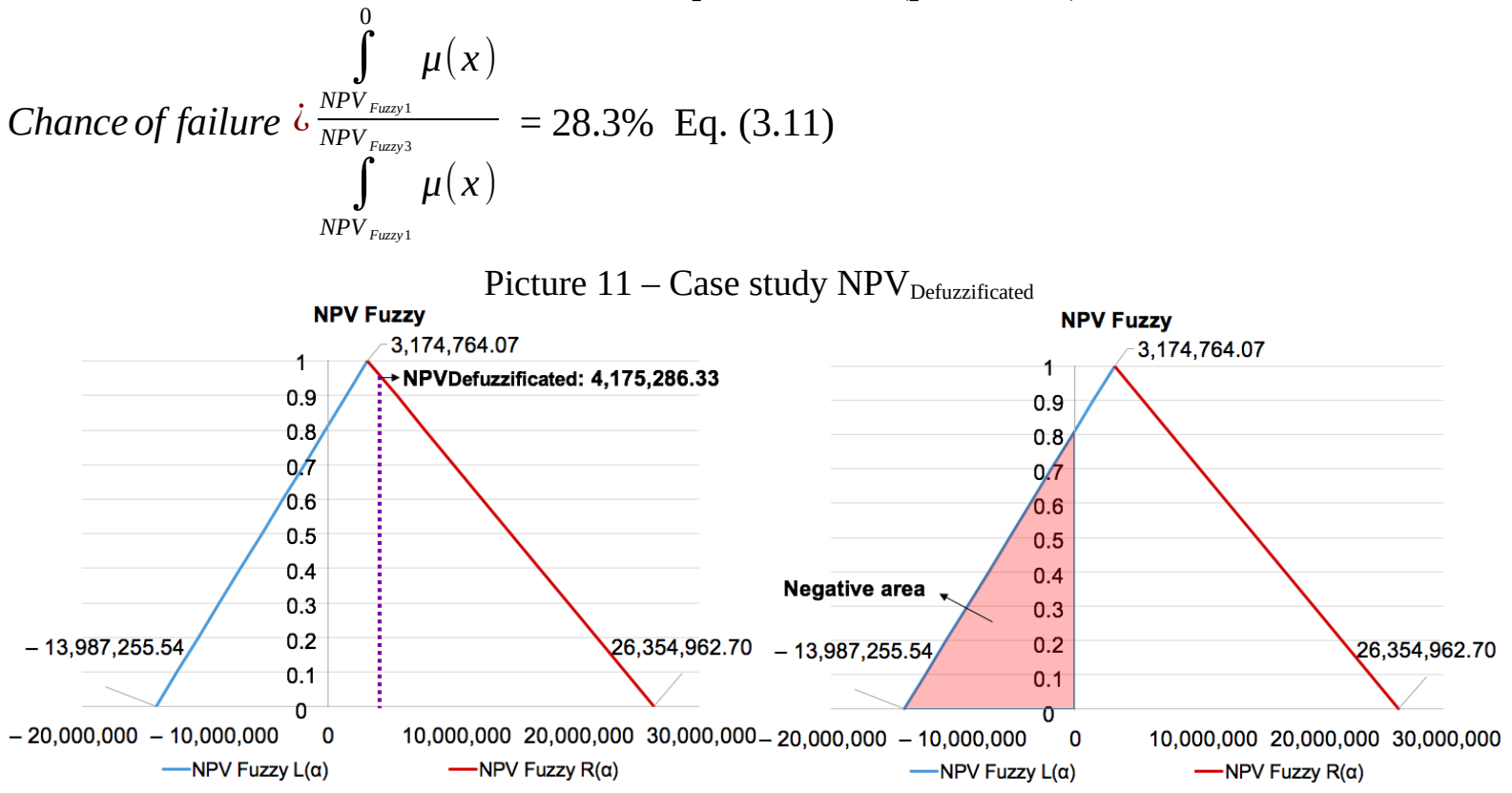

\section{THEME DISCUSSION AND RESULTS}

Intended to show and make use of a model to valuate a project in a simpler way and also considering the economic and financial uncertainties, the fuzzy logic was presented and it was also applied to answer a real Brazilian biofuel project investment question.

For that, the international context was studied and it was observed an intensive and 
continuous increase of the ethanol biofuel production since the start of the Brazilian ethanol program. Besides the government incentive, the fuel is environmentally friendly, with low $\mathrm{CO}_{2}$ emissions, even less than the biodiesel produced by soy.

When applied, the method was proved to be relevant considering many different aspects. Where, for instance can be listed: the supply and demand of the ethanol market, the financial information of the project such as its cash flow and hurdle rate and also the Brazilian basic interest rate. This last one considered the most important rate that affects the national and international economy, since the country is a major exporter of commodities.

All those items present in the project were listed, and also the uncertainties of each one. The investment focused on the acquisition of a 10 million square meter land $-1,000$ hectares or about 2,471 acres - positioned inside São Paulo state; a factory to produce ethanol; machines; equipment and office supplies. The total estimated investment of the project during its 12 years was - R $\$ 27,454,140$.

The land area was chosen based on the minimum sugarcane area to attend the estimated demand of 4,800,000 ethanol liters per year. Therefore, $80 \%$ of the total area would be reserved for plantation, with a production capacity of 5,236,000 liters of the biofuel.

Based on the market selling price positioning, the average value was $\mathrm{R} \$ 1.87$ per liter. The value of R\$ 0.25 per liter of the good remains - sugarcane bagasse - and the freight as R 0.53 per liter were also considered. Those are the main contributions for the project revenue.

The project costs and expenses were divided in those who are influenced or not by the ethanol production. So, the fixed ones took a mark of $-\mathrm{R} \$ 680,000$ per year and the variable ones $-\mathrm{R} \$ 1.15$ by each liter of ethanol produced per year.

Thus, the $\mathrm{R} \$ 12,709,920$ estimated annual revenue and the $-\mathrm{R} \$ 6,200,000$ estimated annual costs and expenses of the project resulted in a $\mathrm{R} \$ 6,509,920$ annual cash flow.

Considering a total tax aliquot of $30 \%$ and a $-\mathrm{R} \$ 405,840$ of annual depreciation during ten years of the factory, machines, equipment and office supplies, the cash flow was divided in two: one from 1 to 10 years - discounting the depreciation from the taxes - and one from 11 to 12 years - where there is no depreciation to be reduced from the taxes.

So, the annual cash flow after taxes from 1 to 10 years was R\$4,678,696 and R\$ 4,556,944 from 11 to 12 years. As expected, the annual cash flow is greater when the depreciation is discounted from the taxes payed.

Finally, using a R $\$ 23,395,740$ assets residual value coming from the land and, using a 14.4\% MARR - 1.5\% above the Selic Brazilian basic interest rate of January 11, 2017, according to the Brazilian Central Bank (2017) -, the R\$3,174,764.07 NPV was calculated.

However, the NPV does not includes the environment uncertainty, and with that intention, fuzzy concept is useful, assigning an oscillation for each project item. The percentage of variation can be based on different aspects, such as market fluctuation interval, parameterization, analogy, forecast studies, inference and even expert opinions. It is shown in table 2 how each component was found and the method used to define their uncertainty:

Table 2 - Case study data source 


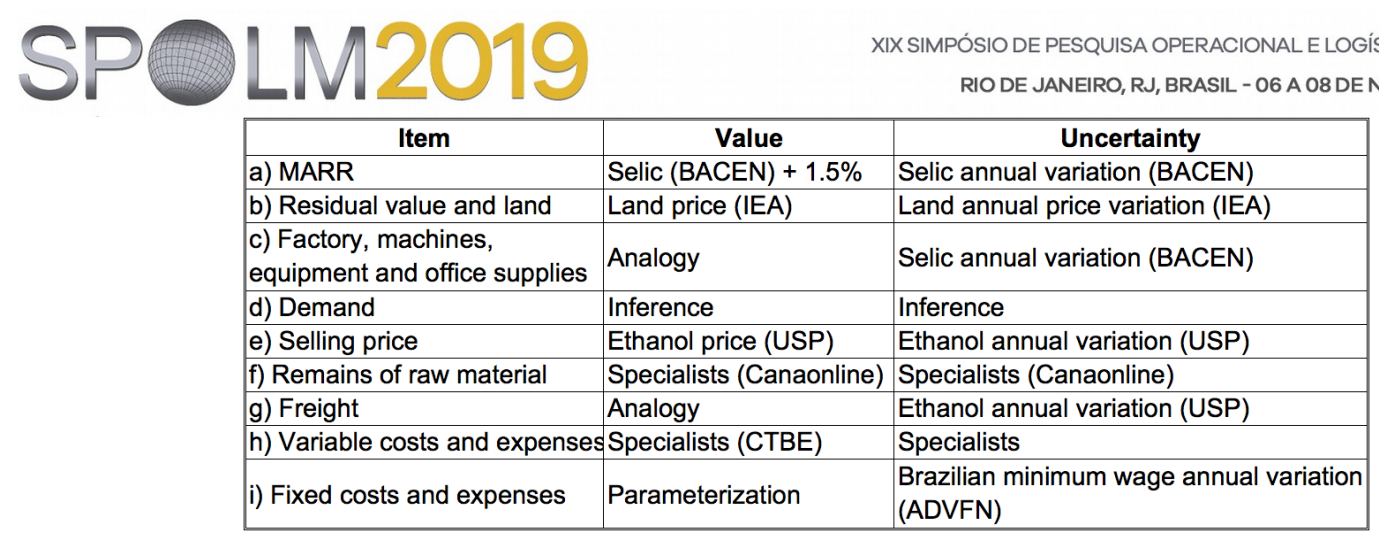

Source: author

Having all the variation determined, the next step was the definition of the fuzzy triangular numbers: the lowest, estimated and highest value. The greater the discrepancy between the extreme numbers, the greater the unpredictability of the future.

The possibility of fluctuating values in fuzzy logic is considerably relevant to bring verisimilitude to the analysis. Which is not found in many methods, including the simple NPV one. That is why the NPV Fuzzy is very adherent to situations of change and unpredictability. In other words, the R\$3,174,764.07 simple NPV calculated does not include all the inconstancy of all the terms that make up its calculation.

It is also important to point out that the $30 \%$ tax aliquot does not have a minimum and maximum. Thus, it has not disparity and cannot be a fuzzy number.

So, having defined all the range of each NPV component, it was possible to define an $\mathrm{NPV}_{\text {Fuzzy }}$ that diverge among $-\mathrm{R} \$ 13,987,255.54$ and $\mathrm{R} \$ 26,354,962.70$, depending on the maximum optimism or pessimism of the project factors.

Despite the range, a more accurate result is required for the project valuation and for that, it is necessary to defuzzificate the $\mathrm{NPV}_{\text {Fuzzy }}$ into a real-world number. The used method was the center of area or centroid, which is the most common and adjusted to the study needs. The result was $\mathrm{R} \$ 4,175,286.33$ for the $\mathrm{NPV}_{\text {Defuzzificated. }}$ It represents a positive value, making possible the disbursement for the execution of the investment project.

Another important raised issue concerns the chance of failure or success of the investment, which can be calculated by the distribution of cumulative possibilities defuzzification. As a result, the chance of failure was determined as only $28.3 \%$. By the other hand, the chance of success, calculated as the complementary part to reach $100 \%$, was $71.7 \%$. A high number that ends encouraging the biofuel ethanol investment in the Brazilian market.

Finally, besides the high investment amount of $-\mathrm{R} \$ 27,454,140.00$ varying $\pm 8.9 \%$ from $-\mathrm{R} \$ 29,896,368.42$ and $-\mathrm{R} \$ 25,011,911.58$, which can be confused as a bad decision, it was proved to be quite profitable, with large annual cash flows.

Even by a less quantitative and more fundamentalist analysis, the scenario of continuous growth, followed by government encouragement, historical profit and industry innovations showed a bright future for ethanol biofuel.

\section{FINAL CONSIDERATIONS}

\subsection{REVIEWS AND COMMENTS}

Despite the insertion of uncertainties in this work, it was delimited to a few, knowing that the environment has countless number of them, such as: unpredictable investments, innovation, waste of production, bad management, limited knowledge, technical failures, loss of operational efficiency, political factors, international economy etc.

Besides that, the absence of a range of possibilities for the NPV would give a distortion of reality, having a micro horizon of vision. The role of fuzzy logic is to bring the 
most relevant information to support the decision making.

Another important point is the technique used to estimate the project items variations. The adoption of subjective methods may compromise a more accurate result, then a better planning and study of the investment project situation may result in more assertiveness, especially in long-terms ones.

The relevance for the research line is the contribution given by fuzzy logic to the project valuation, where it is possible not only to obtain a more realistic NPV, but also, to obtain the percentage of chance of success. The application in a real case study in a simple way makes the work more accessible, such as the widespread tools used to solve it.

\subsection{FUTURE WORKS}

The fuzzy logic has an unlimited application field and can be used to, for instance, find better routes for airplane pilots based on physical, geographic and technical uncertainties. Also, to define geographic positioning of thermonuclear plants, considering avoid population centers, lower cost of freight and gasoline, being close to the raw material and demand etc.

The ease in using fuzzy logic since its creation on the last century are making its use boundless, even unexpected fields like medicine is capable of being used. An example is the use of the method to conduct surgeries far from the patience, even in other countries, using artificial intelligence. This way, for every uncertainty listed, would result in a more appropriated approach. The difficulty lies in the difficulty of mapping and quantifying them.

\section{REFERENCES}

\section{BIBLIOGRAPHIC REFERENCES}

[1] ANP - Agência Nacional do Petróleo, Gás Natural e Biocombustíveis. (2016). Boletim anual de preços: Preços do petróleo, gás natural e combustíveis nos mercados nacional e internacional. Rio de Janeiro: ANP. Available at:

<http://www.anp.gov.br/wwwanp/precos-e-defesa-da-concorrencia/precos/boletimanual-de-precos >. Accessed in: 28 aug. 2017.

[2] Carvalho, N.L., Bortolini, J.G., \& Barcellos, A.L. (2014). Biocombustíveis: uma opção para o desenvolvimento sustentável. Gestão e desenvolvimento em context, 2(2), 32-50.

[3] Chiu, C.Y., \& Park, C.S. (1994). Fuzzy cash flow analysis using present worth criterion. The engineering economist, 39(2), 113-137.

[4] Gomes, L.F.A.M., \& Duarte Jr., A. M. (1991). A avaliação de projetos com múltiplos critérios. Produção, 2(1), 5-19.

[5] Greene, D.L., Hopson, J.L., \& Li, J. (2006). Have we run out of oil yet? Oil peaking analysis from an optimist's perspective. Energy policy, 34(5), 515-531.

[6] Gutiérrez, I. (1989). Fuzzy numbers and the net present value. Sacand. J. Mgmt. 5(2), 149-159.

[7] Kohlepp, G. (2010). Análise da situação da produção de etanol e biodiesel no Brasil. Estudos avançados, 24(68), 223-253. Available at: < $\underline{\text { http://dx.doi.org/10.1590/S0103- }}$ 40142010000100017>. Accessed in: 12 aug. 2017.

[8] Oliveira, M. H. F. (2008). A avaliação econômico-financeira de investimentos sob condição de incerteza: uma comparação entre o método de Monte Carlo e o VPL Fuzzy. 231p. Dissertation (Master). Universidade de São Paulo, São Carlos. 
[9] Oliveira Júnior, H.A. (1999). Lógica difusa: aspectos práticos e aplicações. Rio de Janeiro: Interciência.

[10] Oliveira Júnior, H.A., Caldeira, A.M., Machado, M.A.S., Souza, R.C., \& Transcheit, R. (2007). Inteligência computacional aplicada à administração, economia e engenharia em matlab. São Paulo: Thomson learning.

[11] Paulillo, L.F., Vian, C.E.F., Shikida, P.F.A., \& Mello, F.T. (2007). Álcool combustível e biodiesel no Brasil: quo vadis? Revista de economia e sociologia rural, 45 (3), 531565.

[12] Sanches, A.L. (2003) Avaliação econômica de projetos de investimento em condições de incerteza utilizando números triangulares fuzzy. 221p. Dissertation (Master) UNIFEI, Itajubá.

[13] Shaw, I.S., \& Simões, M.G. (1999). Controle e modelagem fuzzy. São Paulo: Edgar Blütcher.

[14] Zadeh, L.A. (1965). Fuzzy sets. Information and control (Vol 8.)

\section{ELECTRONIC REFERENCES}

[15] ADVFN - Salário mínimo. (2017). Available at:

<https://br.advfn.com/indicadores/salario-minimo>. Accessed in: 28 sep. 2017.

[16] BACEN - Banco Central do Brasil. (2017). Available at:

<http://www.bcb.gov.br/Pec/Copom/Port/taxaSelic.asp>. Accessed in: 10 sep. 2017.

[17] CTBE - National Laboratory of Bioethanol Science and Technology. (2015). Available at: <http://ctbe.cnpem.br/etanol-celulosico-deve-ser-viavel-2020/>. Accessed in: 15 sep. 2017.

[18] IBGE - Instituto Brasileiro de Geografia e Estatística. (2017). Available at: <https://sidra.ibge.gov.br/>. Accessed in: 12 aug. 2017.

[19] IEA - Institute of Agricultural Economics. (2017). Available at: $<$ http://ciagri.iea.sp.gov.br/nia1/precor SEFAZ.aspx?cod tipo=2\&cod sis=9 $>$. Accessed in: 16 aug. 2017.

[20] MME - Ministério de Minas e Energia. (2017). Resenha energética brasileira: exercício de 2016. Available at: <http://www.mme.gov.br/documents/10584/3580498/02++Resenha+Energética+Brasileira+2017+-+ano+ref.+2016+\%28PDF\%29/13d8d958de50-4691-96e3-3ccf53f8e1e4?version=1.0>. Accessed in: 15 aug. 2017.

[21] Parker, M. (2016). U.S. facing glut of ethanol. San Antonio Express News. January 17, 2016. Available at:

$<$ http://www.expressnews.com/business/eagle-ford-energy/article/U-S-facing- glut-ofethanol-6764994.php>. Accessed in: 11 aug. 2017.

[22] Renewable Fuels Association - RFA. (2017). Industry statistics. Available at:

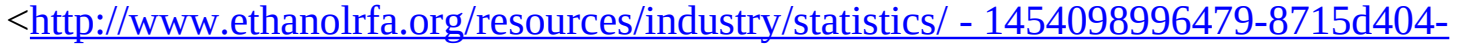
e546>. Accessed in: 12 aug. 2017.

[23] Union of Bioenergy Producers - UDOP. (2016). Produção de etanol de milho ganha espaço na entressafra da cana. Available at: $<$ http://www.udop.com.br/index.php? item=noticias\&cod=1138001 > . Accessed in: 29 sep. 2017. 
[24] University of São Paulo - USP. (2017). Centro de Estudos Avançados em Economia Aplicada - CEPEA. Available at: <https://www.cepea.esalq.usp.br/br/indicador/etanolmensal-sp.aspx >. Accessed in: 22 sep. 2017. 


\section{APPENDIX A - CASE STUDY UNCERTAINTIES}

\begin{tabular}{|c|c|c|c|c|c|c|c|c|c|c|}
\hline \multirow[b]{2}{*}{ Subjects } & \multirow[b]{2}{*}{ Items } & \multirow[b]{2}{*}{ Quantity } & \multirow[b]{2}{*}{ Unit } & \multirow[b]{2}{*}{ Variation ( $( \pm)$} & \multirow[b]{2}{*}{$\begin{array}{c}\text { Depreciation } \\
\text { (years) }\end{array}$} & \multicolumn{3}{|c|}{ Fuzzy triangular numbers } & \multicolumn{2}{|c|}{$\alpha$-cut or $\alpha$ - level } \\
\hline & & & & & & 1 & 2 & 3 & $L(\alpha)$ & $R(\alpha)$ \\
\hline \multirow{2}{*}{ Project } & MARR & $14.4 \%$ & per year & $0.8 \%$ & -1 & \begin{tabular}{l|}
0.136 \\
\end{tabular} & 0.144 & 0.152 & $0.008 \alpha+0.136$ & $-0.008 \alpha+0.152$ \\
\hline & \begin{tabular}{|l|} 
Residual Value \\
\end{tabular} & $23,395,740.00$ & RS & $10.3 \%$ & - & $20,985,978.78$ & $23,395,740.00$ & $25,805,501.22$ & $2,409,761.22 \alpha-20,985,978.78$ & $-2,409,761.22 \alpha+25,805,501.22$ \\
\hline \multirow{5}{*}{ Investment } & Land & $-23,395,740.00$ & RS & $10.3 \%$ & - & \begin{tabular}{|l|}
$-25,805,501.22$ \\
\end{tabular} & $-23,395,740.00$ & $-20,985,978.78$ & $2,409,761.22 \alpha-25,805,501.22$ & $-2,409,761.22$ a $-20,985,978.78$ \\
\hline & Factory & $-1,220,000.00$ & RS & $0.8 \%$ & 10 & $-1,229,760.00$ & $-1,220,000.00$ & $-1,210,240.00$ & $9,760.00 \alpha-1,229,760.00$ & $-9,760.00 \alpha-1,210,240.00$ \\
\hline & Machines and Equipment & $-2,770,400.00$ & RS & $0.8 \%$ & 10 & $-2,792,563.20$ & $-2,770,400.00$ & $-2,748,236.80$ & $22,163.20 \propto-2,792,563.20$ & $-22,163.20 \alpha-2,748,236.80$ \\
\hline & Office Supplies & $-68,000.00$ & RS & $0.8 \%$ & 10 & $-68,544.00$ & $-68,000.00$ & $-67,456.00$ & $544.00 \alpha-68,544.00$ & $-544.00 \propto-67,456.00$ \\
\hline & Total Investment & $-27,454,140.00$ & RS & $8.9 \%$ & - & $-29,896,368.42$ & $-27,454,140.00$ & $\mid-25,011,911.58$ & $2,442,228.42 \alpha-29,896,368.42$ & $-2,442,228.42 \alpha-25,011,911.58$ \\
\hline \multirow{5}{*}{ Revenue } & Demand & $4,800,000$ & liter/year & $23.0 \%$ & - & $3,696,000.00$ & $4,800,000.00$ & $5,904,000.00$ & $1,104,000.00 a+3,696,000.00$ & $-1,104,000.00 \alpha+5,904,000.00$ \\
\hline & \begin{tabular}{|l|} 
Selling Price \\
\end{tabular} & 1.87 & $\mathrm{RS} /$ /iter & $3.4 \%$ & - & 1.80 & 1.87 & 1.93 & $0.06 \alpha+1.80$ & $-0.06 \alpha+1.93$ \\
\hline & Remains of raw material & 0.25 & $\mathrm{R} \$ /$ liter & $-64.7 \%, 76.5 \%$ & - & 0.09 & 0.25 & 0.44 & $0.16 \alpha+0.09$ & $-0.19 \alpha+0.44$ \\
\hline & \begin{tabular}{|l|} 
Freight \\
\end{tabular} & 0.53 & $\mathrm{RS} /$ /iter & $3.4 \%$ & - & 0.51 & 0.53 & 0.55 & $0.02 \alpha+0.51$ & $-0.02 \alpha+0.55$ \\
\hline & Total Revenue & $12,709,920.00$ & RS/year & $-30.1 \%, 35.7 \%$ & - & $8,887,426.33$ & $12,709,920.00$ & $17,243,252.33$ & $3,822,493.67 \alpha+8,887,426.33$ & $-4,533,332.33 \alpha+17,243,252.33$ \\
\hline \multirow{3}{*}{$\begin{array}{l}\text { Costs and } \\
\text { Expenses }\end{array}$} & Variable Costs and Expenses & -1.15 & RS/liter.year & $20.0 \%$ & - & \begin{tabular}{l|l}
-1.38 \\
\end{tabular} & -1.15 & -0.92 & $0.23 \alpha-1.38$ & $-0.23 \alpha-0.92$ \\
\hline & Fixed Costs and Expenses & $-680,000.00$ & RS/year & $9.1 \%$ & - & $-741,880.00$ & $-680,000.00$ & $-618,120.00$ & $61,880.00$ a $-741,880.00$ & $-61,880.00 \alpha-618,120.00$ \\
\hline & Total Costs and Expenses & $-6,200,000.00$ & $\mathrm{RS} /$ year & $5.8 \%, 2.4 \%$ & - & $-5,842,360.00$ & $-6,200,000.00$ & $-6,049,800.00$ & $-357,640.00$ a $-5,842,360.00$ & $-150,200.00 \alpha-6,049,800.00$ \\
\hline \multirow{6}{*}{ Cash Flow } & Cashflow Before Taxes & $6,509,920.00$ & RS/year & $-53.2 \%, 71.9 \%$ & - & $3,045,066.33$ & $6,509,920.00$ & $11,193,452.33$ & $3,464,853.67 \alpha+3,045,066.33$ & $-4,683,532.33 \alpha+11,193,452.33$ \\
\hline & Tax Aliquot & 0.30 & per year & - & - & \multicolumn{3}{|c|}{ Does not have uncertainty } & Does not have uncertainty & Does not have uncertainty \\
\hline & \begin{tabular}{|l|} 
Depreciation \\
\end{tabular} & $-405,840.00$ & RS/year & $0.8 \%$ & - & \begin{tabular}{|c|c|}
$-409,086.72$ \\
\end{tabular} & $-405,840.00$ & $-402,593.28$ & $3,246.72 \alpha \quad-409,086.72$ & $\begin{array}{cc}-3,246.72 \alpha & -402,593.28 \\
\end{array}$ \\
\hline & Cashflow After Taxes $1-10$ years & $4,678,696.00$ & RS/year & $-51.8 \%, 70.1 \%$ & - & $2,254,272.44$ & $4,678,696.00$ & $7,956,194.62$ & $2,424,423.56 \alpha+2,254,272.44$ & $-3,277,498.62 \alpha+7,956,194.62$ \\
\hline & Cashflow After Taxes 11-12 years & $4,556,944.00$ & RS/year & $-53.2 \%, 71.9 \%$ & - & $2,131,546.43$ & $4,556,944.00$ & $7,835,416.63$ & $2,425,397.57 \alpha+2,131,546.43$ & $-3,278,472.63 \alpha+7,835,416.63$ \\
\hline & \begin{tabular}{|l|l|} 
NPV \\
\end{tabular} & $3,174,764.07$ & RS & $-540.6 \%, 730.1 \%$ & - & $-13,987,255.54$ & $3,174,764.07$ & $26,354,962.70$ & $17,162,019.61 \alpha-13,987,255.54$ & $-23,180,198.63 \alpha+26,354,962.70$ \\
\hline
\end{tabular}

